malen meer daartoe den toegang te verleenen, zoodra althans de belangstelling hunnerzijds dit vordert. Intusschen vestigt hij nu. reeds de aandacht der leden op de laatste alinea van art. 3 van het Bibliotheeks-reglement, waarbij den Bibliothecaris de vrijheid wordt verleend ook buiten de vastgestelde dagen aan belangstellenden toegang tot de boekerij te verleenen.

Ter beoordeeling der vraag of en in hoever het reeds aanstonds noodig is de verzameling meer dan tweemaal 's weeks open te stellen, wordt, overeenkomstig het voorstel van den heer Robidé. van der Aa, goedgekeurd, aanteekening van het getal bezoekers te houden.

Daar niemand hierna meer het woord verlangt, stelt de Voorzitter den leden voor het gebouw te bezichtigen, terwijl hij, niets meer aan de orde zijnde, de vergadering sluit.

\title{
190STE BESTUURSVERGADERING.
}

GEHOUDEN 15 JUNI 1878.

Tegenwoordig de heeren Quarles van Ufford (Ondervoorzitter), Corns, de Groot (Penningmeester), Wijnmalen (Secretaris), Kern, Niemann, Meinsma, Juynboll, Robidé van der Aa en Humme. Afwezig de heeren van Rappard, Dumontier en Mirandolle, de twee eerstgenoemden met kennisgeving.

Bij afwezigheid van den Voorzitter, den heer van Rappard, neemt de Onder-voorzitter, de heer Quarles van Ufford, de Voorzittersplaats in.

De notulen van het verhandeide in de vorige Bestuursvergadering worden gelezen en goedgekeurd, waarna eveneens de notulen der Algemeene Vergadering van den 4den Mei Il. worden medegedeeld en voorloopig vastgesteld ter opneming in de Bijdragen.

Door den Secretaris wordt mededeeling gedaan van de sedert de vorige bijeenkomst ingekomen boekwerken. Plaatsing daarvan in de boekerij, terwijl, overeenkomstig het voorstel van den 
Secretaris, besloten wordt in het vervolg de lijst der ingekomen .boekwerken niet meer in de notulen in te lasschen, daar, overeenkomstig alinea 11 van art. 15 van het nieuwe Bibliotheeks-reglement, de Secretaris-Bibliothecaris jaarlijks aan zijn Verslag van den staat der bibliotheek eene volledige lijst moet toevoegen van hare aanwinsten zoowel door aankoop als door geschenken.

Tevens wordt na eenige gedachtenwisseling goedgekeurd de notulen tweemaal 's jaars in de Bijdragen op te nemen en als regel vast te stellen dat telkens vóór de Algemeene jaarlijksche Vergadering in Februari het verhandelde in het afgeloopen jaar gedrukt zij.

De heer de Groot, die kort te voren de vergaderzaal had verlaten, treedt weder binnen en zegt door de Regeering benoemd te zijn tot lid der jury over de klasse $n^{0}$. 43 van de wereldtentoonstelling te Parijs, waardoor hij voor een geruimen tijd de stad zal moeten verlaten. Overeenkomstig zijne voordracht wordt goedgekeurd dat gedurende zijne afwezigheid het Penningmeesterschap worde opgedragen aan den Secretaris, terwijl in zijne plaats als lid in de Bibliotheekscommissie zal optreden het bestuurslid Humme.

Door den tijdelijken Voorzitrer wordt vervolgens aan de orde gesteld de behandeling der vraag, of de door den oudminister van oorlog, P. G. Booms, geleverde studiën over Algiers niet eene plaats in de Bịjdragen zouden kunnen erlangen. Bij de gedachtenwisseling, die hierover plasts heeft, blijkt er verschil van gevoelen te bestaan. Hoewel de Schrijver der studiën zich daarin zorgvuldig onthouden heeft van het maken van vergelijkingen en het aanwijzen van de punten van overeenkomst en verschil tusschen de Algerijnsche en onze koloniale toestanden, kan, zoo wordt eenerzijds beweerd, de objectieve voorstelling, gelijk die hier omtrent de eerste gegeven wordt, bij eene beschouwing der laatste niet van gewicht ontbloot zijn, terwijl bovendien de studiën zelve, waarbij kostbare, niet voor allen toegankelijke bronnen geraadpleegd zijn, eene plaatsing in het Tijdschrift alleszins zouden rechtvaardigen. Enkele leden wenschen dit gaarne toe te geven, houden zich zelfs overtuigd van het hooge beiang van den geleverden arbeid, voor de degelijkheid waarvan de persoonlijkheid wan den Auteur 
alle warborgen oplevert, doch zij meenen zich in beginsel te moeten verzetten tegen opneming van opstellen, waardoor de kring der werkzaamheden van het Instituut zou worden uitgebreid, tot schade wellicht van de belangen, tot bevordering waarvan het Instituut in de eerste plaats geroepen is. Van deze zijde zou men echter dit bezwaar, waarvan het gewicht eenstemmig wordt erkend, niet verder doen gelden, mits men zich slechts niet door de opneming dezer studiën over Algiers voor het vervolg de handen zou gebonden achten, wanneer ons soms meerdere dergelijke stukken mochten worden aangeboden. Te minder zou men bovendien er zich nu tegen verzetten, waar door de plaatsing dier opstellen de uitgave van andere reeds goedgekeurde stukken niet werd belemmerd. Met algemeene stemmen wordt ten slotte besloten den generaal Booms uit te noodigen zijue studiën, met drie schetskaarten verrijkt, voor de Bijdragen af te staan en de zorg voor den druk daarvan in de eerstvolgende aflevering aan den Secretaris opgedragen, die tevens gemachtigd wordt dit jaar bovendien nog eene aflevering het licht te doen zien, waarin de nog voorhanden stukken kunnen worden opgenomen, terwijl besloten wordt het reeds door 't medelid A. Ligtvoet aangeboden omvangrijk Dagboek van de vorsten van Goa en Tello voor een der volgende deelen der Bijdragen te bestemmen.

Door den tijdelijken Voorzitter wordt verder mededeeling gedaan van:

10. de missives der heeren S. Locker de Bruyn en P. A. Leupe, beiden te 's Gravenhage, houdende bericht van de aanneming hunner benoeming, de eerste tot lid, de tweede tot correspondeerend lid van het Instituut. Aangenomen voor kennisgeving.

20. eene missive van jhr. mr. A. Baud, berichtende de aanneming zijner benoeming tot lid van het Instituut, onder aanbieding voorts van eene beeldtenis van wijlen zijn Vader, waarmede het Instituut zich moet vergenoegen tot tijd en wijlen een exemplaar der beter gelijkenende lithografie door den heer Mieling, zooals eigenlijk verlangd wordt, wegens sterfgeval van een der vrienden of vereerders van wijlen zijn vader, beschikbaar kome.

Aan den heer Baud zal de dank der vergadering voor zijn gescnenk worden aangeboden. 
30. eene missive van het Smithsonian Institution, houdende dankbetuiging voor de gezonden Bijdragen. Voor kennisgeving aangenomen.

Naar aanleiding van een in de vorige vergadering meêgedeeld schrijven van den heer J. E. van den Bor, die ontkent lid te zijn van het Instituut, worden door den Secretaris eenige inlichtingen verstrekt, waaruit blijkt, dat de heer J. E. van den Bor, bij gelegenheid van het zilveren feest van het Instituut tot lid is benoemd; dat hem, destijds resident van de Lampongs, daarheen de benoemingsbrief is verzonden door tusschenkomst van Commissarissen te Batavia; dat hij inmiddels vóór den ontvangst daarvan Indië heeft verlaten, terwijl in de eerste tijden zijn adres hier te lande onbekend scheen; zonder echter met zijn antwoord bekend te zijn, heeft men hem voorloopig niet van de ledenlijst afgevoerd. Op voorstel van den Secretaris wordt besloten den heer van den Bor, onder mededeeling van een en ander, uittenoodigen het lidmaatschap van het Instituut te willen aanvaarden.

Daar van den heer W. A. Jellinghaus, oud-resident te Batavia, tot dusver geen antwoord is ingekomen op zijne benoeming tot lid van het Instituut, wordt de Secretaris gemachtigd te onderzoeken, of het bericht daarvan wel in handen van den benoemde is gekomen.

Door den Secretaris wordt ter tafel gebracht een exemplaar 10. van de "Javaansche vertellingen, bevattende de lotgevallen van een kantjil, een reebok en andere dieren. Voor de uitgave bewerkt door Dr. W. Palmer van den Broek" ; en 20. van de "Bloemlezing der Maleische letterkunde, door G. K. Niemann"; onder mededeeling voorts, dat de door het Departement van Koloniën bestelde exemplaren van beide werken gereed zijn en eerlang zullen verzonden worden met bijvoeging van de noodige declaratiën.

Van Dr. A. Bruining, te Kuinre (Overijssel), is ontvangen het vervolg van zijne vertaling van Cankara âcârya's Aphorismen op den Vedanta. Ter plaatsing in de Bijdragen in handen gesteld van den Secretaris. 
Door de heeren Quarles van Ufford en Robidé van der Aa worden schriftelijke rapporten uitgebracht over de door den heer Leupe ingezonden en in hunne handen gestelde stukken, getiteld: "Een onderzoek naar den toestand der Bataviasche groote rivier in 1701" en "Het eiland Soemba in 1759." Beide adviseeren tot opneming daarvan in de Bijdragen met inachtneming van enkele opmerkingen, waarmede de Schrijver moet worden in kennis gesteld. Dienovereenkomstig wordt besloten.

Door den heer Niemann wordt vervolgens verslag nitgebracht omtrent de in zijne handen gestelde papieren van wijlen Hoepermans, door het lid mr. van Musschenbroek aan het Instituut gezonden. Het luidt als volgt:

"De van wijlen Hoepermans afkomstige stukken, door mr. van Musschenbroek aan het Instituut gezonden, hebben allen betrekking op oudheden uit het Hindoetijdperk van Java, meerendeels aangetroffen in de residentiën Kediri, Madijoen, Kĕdoe, Cheribon en de Vorstenlanden. Het door Hoepermans geleverde bestaat in af beeldingen van voorwerpen, platte gronden van tempels, facsimilés van opschriften, meestal jaartallen, vergezeld van korte of somtijds meer uitvoerige mededeelingen omtrent een en ander. De belangrijkste oudheden, waarvan hier teekeningen en beschrijvingen gegeven worden, zooals de rüne van Panataran, de bij Soekoeh en Tjětô gevondene overblijfselen en de tempels van Prambanan zijn reeds door verscheidene geschriften in meerdere of mindere mate bekend geworden; hetgeen Hoepermans daarvan meldt, kan hier en daar tot aanvulling van onze kennis dienen. Omtrent sommige andere ondheden, in Madijoen, Kĕdiri, Cheribon enz. ontdekt, ontbreekt het hier ook niet aan bijzonderheden, die nog nieuw zijn voor de wetenschap. Het komt mij echter voor dat de stukken van Hoepermans, zooals die daar liggen, niet geschikt zijn voor opeubaarmaking door den druk, zoowel om het fragmentarische van zijne mededeelingen als wegens de minder gepaste opmerkingen die hier en daar voorkomen; ook hebben wij geen waarborg dat zijne reproductie van de opschriften zooveel mogelijk getrouw en nauwkeurig is te noemen. Om deze redenen zou ik in bedenking geven den heer van Musschenbroek te verzoeken deze stukken in de bibliotheek van het Instituut te deponeren, opdat zij, die zich met het onderzoek der Hin- 
doesche oudheden van Java bezig houden, hier in de gelegenheid gesteld worden inzage te nemen van hetgeen Hoepermans heeft nagelaten."

De vergadering vereenigt zich met dit advies, terwijl besloten wordt daarvan den heer van Musschenbroek mededeeling te doen.

Op voorstel van den Secretaris wordt besloten de behandeling van de concept-overeenkomst met den drukker uit te stellen, totdat ook die met den uitgever ter tafel kan worden gebracht.

Door den Secretaris, die, ingevolge de bepalingen van het met $10 \mathrm{Mei}$ in werking getreden Bibliotheeks-reglement, met het beheer en dagelijksch toezicht over de bibliotheken van het Instituut en Indisch Genootschap belast is, wordt verslag uitgebracht omtrent hetgeen door hem als Bibliothecaris sedert verricht is. Wat in de eerste plaats de overdracht betreft van het beheer over de boekerij van het Indisch Genootschap : overeenkomstig de bepalingen van het contract wordt overgelegd een schrijven van het Bestuur van het Genootschap, gedagteekend 8 Mei 1878, ten geleide: 10. van twee gewaarmerkte exemplaren van den catalogus en de beide supplementen daarop; 20. van een drietal mede door het Bestuur onderteekende lysten van vermiste en uitgeleende boeken, en van die boeken, waarmede de boekerij sedert de uitgave van het $2 \mathrm{e}$ supplement is verrijkt geworden; met verzoek, tegelijk met het bericht der overname, éen der beide exemplaren, eveneens vanwege het Instituut behoorlijk gewaarmerkt, terug te zenden. Overeenkomstig het advies van den Secretaris-Bibliothecaris wordt besloten aan het Bestuur van het Indisch Genootschap mededeeling te doen, dat de overname van het beheer over de boekerij heeft plaats gehad, met terugzending tevens van een der mede vanwege het Instituut gewaarmerkte exemplaren der overgelegde catalogi en lijsten, terwijl het ander exemplaar daarvan in het archief van het Instituut zal worden gedeponeerd.

De Secretaris bericht verder, dat hij, voor zooveel hem dit reeds mogelijk was, gevolg heeft gegeven aan de voorschriften van het Bibliotheeks-reglement, voornamelijk met betrekking tot de catalogi van de beide boekverzamelingen. Zoowel de systematische als de alphabetische catalogus der bibliotheek van het Indisch Genootschap is door hem gereed gemaakt en in de leeszaal aanwezig, in doozen geborgen, en bestaande uit losse 
kaarten, in cartonnen bandjes gebonden, terwijl bovendien registers zijn aangelegd, vermeldende de aanwinsten der beide verzamelingen zoowel door aankoop als door geschenken.

Wat echter den catalogus der boek- en handschriften-verzameling van het Instituut betreft, deze is geheel onvoldoende; de geheele verzameling moet opnieuw gecatalogiseerd worden, met welken arbeid de Secretaris aanstonds een aanvang heeft gemaakt, terwijl, in afwachting van den nieuwen inventaris, de oude zooveel doenlijk voor den dienst in de leeszaal is geschikt gemaakt.

De staat, waarin de boekerij zelve zich bevindt, laat veel te wenschen over; niet enkel is er weinig gedaan voor het binden der boeken, maar een overgroot aantal tijdschriften en genootschapswerken munt uit door onvolledigheid. De Secretaris verzoekt dientengevolge machtiging om aan de verschillende genootschappen en redactiën, wier werken onvolledig voorhanden zijn, aanvulling te verzoeken van de ontbrekende gedrukten. Dienovereenkomstig word̀t besloten, terwịl, naar aanleiding eener opmerking van het bestuurslid Juynboll, den Secretaris tevens de machtiging wordt verleend, het ontbrekende, zoo noodig, door aankoop aan te vullen.

Verder wordt door den Secretaris er op gewezen dat in de bibliotheek onderscheidene genootschappen en tijdschriften, die de bevordering van de Indische taal-, land- en volkenkunde bedoelen, niet of gebrekkig vertegenwoordigd rijn ; ook mist men, op eene enkele uitzondering na, de organen der verschillende Zendingsvereenigingen, die haar arbeidsveld in onzen Indischen Archipel hebben. Met het oog op een en ander wordt besloten :

10. zich in betrekking te stellen met de Koninklijke Natuurkundige Vereeniging in Ned.-Indië, met de Vereeniging voor geneeskundige wetenschappen in Ned.-Indië en het Indisch Landbouwgenootschap; voorts met de Société d'Ethnographie, de Société académique Indo-Chinoise en de Société des études maritimes et coloniales, de lantste drie te Parijs gevestigd;

20. aan de redactiën van het Indisch militair Tijdschrift, het Recht in Ned.-Indië, het Schoolblad, Orgaan van de Onderwijzers-vereeniging, en het Oesterr. Monatsschrift für den Orient, te Weenen, voor te slaan hare organen voor de bibliotheek van het Instituut te zenden tegen ruiling van de Bijdragen; en 30. den Secretaris-Bibliothecaris te machtigen zoowel bij het 
Ned. Bịbelgenootschap als bij de onderscheidene Zendingsvereenigingen hier te lande stappen te doen tot het verkrijgen van een volledig exemplaar harer werken, verslagen of berichten, of wel, zoo ze reeds gedeeltelịk aanwezig zijn, tot het aanvullen der vitgaven : een en ander onder aanbieding onzerzịjds van een exemplaar onzer gedrukten of aanvulling van het ontbrekende.

De aandacht der Vergadering wordt gevestigd op het boekenfonds van het Instituut, dat sedert 10. Mei l.l., in 't lokaal overgebracht, onder beheer van den Secretaris is gekomen en waaronder een vrị aanzienlijk gedeelte uit Javaansehe en Maleische werken bestaat, die, naar men meent, alsnog met vrucht in Indië in den handel zouden kunnen worden gebracht. De Secretaris wordt gemachtigd in overleg met den Uitgever daartoe het noodige te verrichten.

Aan de orde is eindelijk de behandeling van het reeds vroeger ingediend voorstel van heeren Commissarissen in Ned. Indië tot uitgave van de Nieuwe Statuten van Batavia. Wegens het vergevorderd uur wordt op voorstel van den Voorzitter besloten dit punt tot eene volgende bijeenkomst aan te houden, waarna de Vergadering, niets meer aan de orde zijnde, door den Voorzitter gesloten wordt.

\section{STE BESTUURSVERGADERING.}

GEHOUDEN 28 SEPTEMBER 1878.

Tegenwoordig de heeren van Rappard (Voorzitter), Corns. de Groot (Penningmeester), Wijnmalen (Secretaris), Dumontier, Juynboll, Meinsma, Niemann, Kern en Humme. Afwezig de heerer Mirandolle, Robidé van der Aa en Quarles van Ufforde

De notulen van het verhandelde in de vorige vergadering worden gelezen en goedgekeurd.

Door den Secretaris wordt mededeeling gedaan van de sedert de vorige bijeenkomst ontvangen tijdschriften en afzonderlijke 